\title{
Using rodents for modeling Self-Injurious Behaviour Mehrnoosh Jafari
}

\author{
Address: Faculty of Veterinary Medicine, University of Tehran, Tehran, Iran \\ from International Society on Brain and Behaviour: 3rd International Congress on Brain and Behaviour \\ Thessaloniki, Greece. 28 November - 2 December 2007 \\ Published: 17 April 2008 \\ Annals of General Psychiatry 2008, 7(SuppI I):S290 doi:10.1 186/1744-859X-7-SI-S290
}

This abstract is available from: http://www.annals-general-psychiatry.com/content/7/SI/S290

(c) 2008 Jafari; licensee BioMed Central Ltd.

\section{Background}

Self-injurious behaviour(SIB) is referred to any kind of behaviour that can cause harm to body tissues without the intention of attempting suicide, such as cutting, scraping, burning, biting or hitting. It's also a severe problem in retarded and autistic children and some genetically inherited diseases like Lesch-Nyhan syndrome.

\section{Materials and methods}

As it's difficult to study abnormal psychological behaviours in humans because of different or unknown backgrounds, it's not uncommon to have animal models to study disorders in a controlled situation. For SIB the most models used are rodents (rats and mice) though there's been reports of SIB in captive rhesus monkeys. Drugs used to induce this behaviour in rodents are pemoline [1], amphetamine, caffeine [2] \& clonidine [3].

\section{Results}

Studys show that SIB can be induced in rodents by increasing the levels of dopamine, glutamate [4] and opiates and decreasing serotonin in central nervous system.

\section{Conclusions}

Though the mechanisms for SIB are still unknown, it's thought that dopamine has the main role in causing it.

\section{References}

I. Bhattacharya SK, Jaiswal AK, Mukhopadhyay M, Datla KP: Clonidineinduced automutilation in mice as a laboratory model for clinical self-injurious behaviour. J Psychiatr Res 1988, 22(I):43-50.

2. King BH, Cromwell HC, Lee HT, Behrstock SP, Schmanke T, Maidment NT: Dopaminergic and glutamatergic interactions in the expression of self-injurious behavior. Dev Neurosci 1998, 20(2-3): 180-187.

3. Mueller K, Nyhan WL: Pharmacologic control of pemoline induced self-injurious behavior in rats. Pharmacol Biochem Behav 1982, I6(6):957-963. Jun
4. Mueller K, Saboda S, Palmour R, Nyhan WL: Self-injurious behavior produced in rats by daily caffeine and continuous amphetamine. Pharmacol Biochem Behav 1982, 17(4):6|3-617. Oct 